\title{
Model Organisms and Model Environments: A Rodent Laboratory in Science, Medicine and Society
}

\author{
EDMUND RAMSDEN*
}

Keywords: Model Organisms; Model Environments; Laboratory; City; Crowding; Stress

In recent years there has been increasing interest in the role of animals in science and medicine. While historians have tended to focus on the processes of standardisation, increasing attention is being given to the surprising and unexpected elements of the model organism. Experimental organisms are, simultaneously, both artefacts and samples of nature. ${ }^{1}$ Rachel Ankeny and Sabina Leonelli put it clearly and succinctly: 'they are systems that have been engineered and modified to enable the controlled investigation of specific phenomena, yet at the same time they remain largely mysterious products of millennia of evolution, whose behaviours, structures, and physiology are for the most part still relatively ill-understood by scientists. ${ }^{2}$ In continuously generating new questions, organisms provide novelty so essential to successful experimental systems. They are, as Hans-Jörg Rheinberger would argue, scientific objects or 'epistemic things', not merely predictable 'technical objects'. 3

What I would like to do is extend this approach further, considering not simply the organism, but the material structures that support it which are all too often taken for granted in the history of science and medicine. I think that we need to add to the history of the model organism, a focus on healthy environments, even sick buildings, in our study of laboratory spaces. Research that depends on the use of animals also depends upon the built environments and infrastructures that surround them. There was a great interest, for example, in standardising food, lighting, and cage size. ${ }^{4}$ In my own research I have looked at the laboratory practices of the physiologist and psycho-biologist Curt Richter. Richter was doing innovative work with rats, wild and domesticated, as part of a programme at Johns Hopkins instigated in 1942 to develop new ways to control Baltimore's

(C) Edmund Ramsden, 2011.

* Edmund Ramsden, Research Fellow, Centre for Medical History, University of Exeter, Amory Building, Rennes Drive, Exeter, Devon EX4 4RJ,

UK. Email: E.Ramsden@exeter.ac.uk

\footnotetext{
${ }^{1}$ Sabina Leonelli, 'Growing Weed, Producing Knowledge: An Epistemic History of Arabidopsis thaliana', History and Philosophy of the Life Sciences, 29 (2007), 193-224.

${ }^{2}$ Rachel A. Ankeny and Sabina Leonelli, 'What's So Special About Model Organisms?', Studies in
}

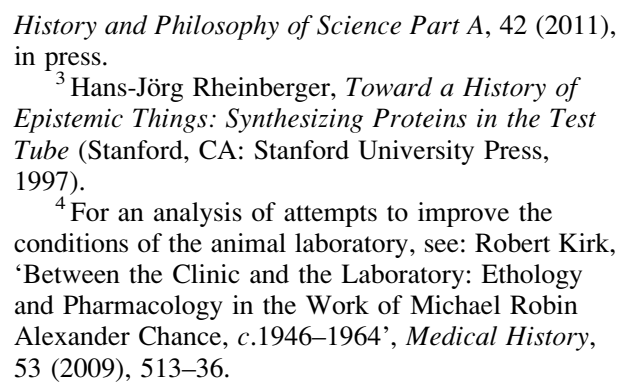
in press.

${ }^{3}$ Hans-Jörg Rheinberger, Toward a History of Epistemic Things: Synthesizing Proteins in the Test Tube (Stanford, CA: Stanford University Press, 1997).

${ }^{4}$ For an analysis of attempts to improve the conditions of the animal laboratory, see: Robert Kirk, 'Between the Clinic and the Laboratory: Ethology and Pharmacology in the Work of Michael Robin Alexander Chance, c.1946-1964', Medical History, 53 (2009), 513-36. 


\section{Edmund Ramsden}

burgeoning rat population. ${ }^{5}$ For Richter, the rat was the ultimate model organism: 'If someone were to give me the power to create an animal most useful for all types of studies on problems concerned directly or indirectly with human welfare, I could not possibly improve on the Norway rat. ${ }^{6}$

He was also immensely proud of his design for holding, breeding and caring for the rat. He described himself as a tinkerer, a scavenger, one who is very open to the unpredictability of his organisms. ${ }^{7}$ But in order to make use of this unpredictability, he needed to standardise his laboratory spaces. Richter designed his own cages - row upon row, all neatly stacked together. His animals were isolated in uniform cages, mechanised to provide him with an endless stream of behavioural and physiological data: as Richter stated: 'The use of our cages makes it possible to put very definite questions to the rats, and to get definite answers' ${ }^{8}$

The rodent control project became the Rodent Ecology Project in 1945, as the scientists and their sponsors turned their attention to the ways in which alterations in the environment could be used to control populations much more effectively. ${ }^{9}$ For John B. Calhoun, who joined the project as a research assistant in 1946, Richter's cages may have been convenient and productive, but they were also immensely damaging to the animal. ${ }^{10}$ For Calhoun, rats were social creatures - they needed company, or they would suffer psychological and physiological breakdown. Always seeking to suggest connections between the rodent laboratory and urban society, Calhoun declared: 'The animals are housed in sterile jail cells... Pruitt Igoe! Are more plush high rises or replicated suburban sprawl any different? ${ }^{11}$

Calhoun designed a new series of experiments in which he placed a number of rats in a quarter-acre pen behind his house in Towson, Maryland. He provided them with unlimited amounts of food and water, and allowed their numbers to grow. His aim was to develop an understanding of rat society. He even wrote of the need to allow the animals to 'speak' to him. ${ }^{12}$ Speak they did, through the expression of a range of pathological behaviours that he found he could control through the design of his model environments.

Once employed at the National Institutes of Mental Health from 1954, Calhoun began to make ever more elaborate 'rat cities'. In his most famous publication, 'Population Density and Social Pathology', published in Scientific American in 1962, he described three experiments. ${ }^{13}$ Calhoun placed a number of rats in a laboratory in a converted barn. He had divided the space into four sections, connected by a series of ramps - two

\footnotetext{
${ }^{5}$ For an analysis of this project, and the various different experimental systems employed in it, see the forthcoming article by the author in the journal, History of the Human Sciences.

${ }^{6}$ C.P. Richter, 'Experiences of a Reluctant RatCatcher: The Common Norway Rat - Friend or Enemy?', Proceedings of the American Philosophical Society, 112 (1968), 403-15.

${ }^{7}$ Jay Schulkin, Curt Richter: A Life in the Laboratory (Baltimore: Johns Hopkins University Press, 2005).

${ }^{8}$ C.P. Richter, 'It's a Long Long Way to Tipperary, The Land of my Genes', in D.A. Dewsbury (ed.), Leaders in the Study of Animal Behavior: Autobiographical Perspectives
}

(Lewisberg: Bucknell University Press, 1985), 377.

${ }^{9}$ Christine Keiner, 'Wartime Rat Control, Rodent Ecology, and the Rise and Fall of Chemical Rodenticides', Endeavour, 29 (2005), 119-25.

${ }^{10}$ For a much more detailed analysis of Calhoun's work and its influence in the social and behavioural sciences, see the forthcoming article by the author in the journal, Isis, 102 (2011).

${ }^{11}$ John B. Calhoun, 'Experimental Socio-physical Environments', URBS Doc 249, 3 December 1975, John B. Calhoun Papers, Box 8b, University of Wyoming.

${ }^{12}$ Ibid.

${ }^{13}$ John B. Calhoun, 'Population Density and Social Pathology', Scientific American, 306 (1962), 139-48. 


\section{Model Organisms and Model Environments}

compartments with only one entry and exit point, the other two with two ramps provided. With unlimited amounts of food and water, the population was again allowed to grow until they numbered eighty adult animals. The animals could have spread out to realise a density of twenty per cage. However, those pens with only one ramp made them possible to defend and control by a dominant male who then lived a relatively normal existence with a 'harem' of approximately ten females. The rest of the animals were crowded into the indefensible pens. As a result of this crowding, a series of pathologies emerged: violence; sexual deviance, such as hyper-sexuality and even 'homosexuality'; submissiveness and withdrawal; the breakdown of maternal care. With a more extensive series of experiments with mice, these pathologies led to high rates of morbidity, mortality and, in time, the extinction of the experimental population. ${ }^{14}$

Calhoun saw his rats and mice as models for man: social and psychological, and physiological breakdown was a common response of all social animals to crowded environments. He responded to criticism that his rodent universes were unnatural environments, by emphasising that this was precisely the point. He had placed his model organisms in a model 'urban' space, complete with tower blocks, cafeterias and congested stairwells. For Calhoun, it was not just the animals that were active in an experimental system, but the spaces in which they existed. The architecture of the rodent laboratory was not simply a technical object, but was an important and active object of study. Space organised and determined every aspect of social life - communication, identity, hierarchy and behaviour. Through the more effective design of space and the control of interaction, Calhoun was attempting to develop more collaborative and intelligent rodent communities, capable of withstanding ever greater degrees of population density.

The influence of Calhoun's experiments can be seen everywhere, not least in popular culture, where it was seen to mirror the problems of American society in the post-war era. ${ }^{15}$ Calhoun's success in generating renewed interest in the problem of the crowd among social scientists was particularly remarkable, particularly when we consider the history of troubled relations with radical behaviourism, hereditary determinism and eugenics. The research on human populations followed three strategies: the use of statistical correlations between density and various pathologies seen as comparable with those witnessed in Calhoun's crowded pens; ${ }^{16}$ experimental studies with subjects in the laboratory; ${ }^{17}$ and field studies in which the behaviour of individuals was observed in real-life crowded environments, such as hospitals, schools and prisons. ${ }^{18}$

The results of the studies were, however, very inconsistent. Some ecological studies showed small positive correlations, others negative associations, and some, the greater

\footnotetext{
${ }^{14}$ John B. Calhoun, 'Death Squared: The Explosive Growth and Demise of a Mouse Population', Proceedings of the Royal Society of Medicine, 66 (1973), 80-9.

${ }^{15}$ For an analysis of Calhoun's influence in popular culture, see: Edmund Ramsden and Jon Adams, 'Escaping the Laboratory: The Rodent Experiments of John B. Calhoun and their Cultural Influence', Journal of Social History, 42 (2009), 761-92.

${ }^{16}$ See Omar R. Galle, W.R. Gove, and J.M. McPherson, 'Population Density and Pathology: What are the Relations for Man?', Science, 176
}

(1972), 23-60; H.H. Winsborough, 'The Social Consequences of High Population Density', Law and Contemporary Problems, 10 (1965), 120-6. For a very critical appraisal of these studies, see Harvey Choldin, 'Urban Density and Pathology', Annual Review of Sociology, 4 (1978), 91-113.

${ }^{17}$ Jonathan L. Freedman, Crowding and Behavior (San Francisco, CA: W. H. Freeman, 1975).

${ }^{18}$ See H. M. Proshansky, W. H. Ittelson, and L. G. Rivlin (eds), Environmental Psychology: Man and His Physical Setting (New York: Holt, Rinehart and Winston, 1970). 


\section{Edmund Ramsden}

significance of variables such as poverty. Experimental laboratory studies also provided inconsistent and insignificant results. For an emerging group of environmental psychologists, however, it was essential that the physical environments chosen by the social or behavioural scientist were analogous to the environment of Calhoun - conditions with confined people against their wishes in crowded spaces for considerable periods.

One of the most successful series of studies focused on the college dormitory. ${ }^{19}$ By comparing the results of a study of two different environments, one, a large corridor dormitory, and the other, a suite-style, sub-divided into smaller communities, psychologists provided evidence of both pathology and the potential for its amelioration. In the corridor, students perceived the environment as crowded and exhibited increased stress levels, which affected health and academic success. In the latter, through breaking up the space, they successfully reduced unwanted social interaction without significantly decreasing density. In the cases of prisons also, Calhoun's work was used in a series of legal challenges that demanded that prisoners be provided with more single cells to provide them with the privacy essential to preserving their mental and physical health. ${ }^{20}$

However, there were also psychiatrists and sociologists concerned that this new architectural determinism was turning attention away from more fundamental problems of social inequality - the real cause of mental health problems in the city. For these social scientists, human beings were intelligent and creative, easily capable of adapting to conditions of high population density. Calhoun now served as a point of attack, a means of questioning this growing obsession with the crowd in the social and health sciences. The sociologists Claude Fischer and Mark Baldassare declared: 'A red-eyed, sharp-fanged obsession about urban life stalks contemporary thought. ${ }^{21}$ The significance of Calhoun's experimental architecture to facilitate, and ameliorate, crowding stress was ignored. The focus became that of the model organism. The failure to find evidence of crowding stress through the earlier statistical studies and laboratory experiments could, therefore, only be explained by fundamental differences between humans and other animals.

While the identification of 'crowding stress' among both human and non-human animals was important to the success of Calhoun's experiments, equally important was his experimental architecture. Indeed, while the model organism allows for mediation between knowledge and phenomena, as well as serving as a point of intervention, ${ }^{22}$ when detached from the model environment, Calhoun's crowded animals became a means of emphasising the threat, to both science and the city, of the search 'for a black plague common to mice and men'. ${ }^{23}$

\footnotetext{
${ }^{19}$ Andrew Baum and Stuart Valins, Architecture and Social Behavior: Psychological Studies of Social Density (Hillsdale, N.J.: Lawrence Erlbaum, 1977); Edmund Ramsden, 'Travelling Facts About Crowded Rats: Rodent Experimentation and the Human Sciences', in Peter Howlett and Mary S. Morgan (eds), How Well Do Facts Travel?: The Dissemination of Reliable Knowledge (Cambridge: Cambridge University Press, 2011), 223-51.

${ }^{20}$ Paul Paulus, Prison Crowding: A Psychological Perspective (New York: Springer-Verlag, 1988).
}

${ }^{21}$ Claude S. Fischer and Mark Baldassare, 'How Far from the Madding Crowd?', New Society, 32 (1975), 531-3: 531.

${ }^{22}$ M. Morrison and M.S. Morgan, 'Models as Mediating Instruments', in idem (eds), Models as Mediators: Perspectives on Natural and Social Science (Cambridge: Cambridge University Press, 1999). See again Ankeny and Leonelli, op. cit. (note 2 ), for an insightful analysis of this approach in the context of model organisms.

${ }^{23}$ Mark Baldassare, Residential Crowding in Urban America (Berkeley: University of California Press, 1979), 46. 